\title{
Organ Donation Rate in Brain-Dead Patients in a Tertiary Referral Center
}

Sir,

Ever since the first organ (kidney) transplant which took place in the 1970s in India, there has been a little progress in this field. ${ }^{[1]}$ Awareness about organ donation from brain-dead donors among Indians, and surprisingly doctors, remains limited. ${ }^{[2]}$ The organ donation rate from deceased donors in India is only 0.26 per million, as compared to 25.6 per million in the United States, 18.3 per million in the United Kingdom, and 32 per million in Spain. ${ }^{[3]}$

We present the findings of a retrospective study of patients fulfilling brain death criteria as per the Transplantation of Human Organs and Tissue (Amendment) Act, ${ }^{[4]}$ admitted over 9 years from January 2009 to December 2017. The objective of this study was to analyze the trend in organ donation from brain-dead patients in a tertiary care referral hospital. The study period was divided into intervals of 3 years each. Of 55 patients who were identified as brain dead, 10 became organ donors. The rate of conversion was noted to increase from $11 \%$ in the $2009-2011$ interval to $40 \%$ in the 2015-2017 interval. The majority of donors were males, with a male:female ratio of $3: 1$ and a mean age of $58.6 \pm 3.6$ years. Organ donors were divided into either those with neurological or traumatic causes of brainstem death (BSD) with 24 patients in neurology group and 31 in trauma group [Table 1]. The most common causes of BSD were trauma from road traffic accidents and nontraumatic intracranial hemorrhage. Other causes were hypoxic-ischemic encephalopathy postcardiac arrest, stroke, and trauma from falls.

The average time recorded from injury to certification of brain death was $45.46 \pm 6.5 \mathrm{~h}$ and from certification of brain death to organ harvesting was $28.26 \pm 4.3 \mathrm{~h}$. Organ harvested in all cases was kidneys, liver, and cornea. All the brain-dead donors were optimized using a standard international protocol $\left[{ }^{[5]}\right.$ Hormonal resuscitation was done with methylprednisolone and thyroxin. Hypotension and diabetes insipidus were the commonly observed complications of BSD. These complications were managed with noradrenaline, vasopressin, and desmopressin. The management of potential organ donor in BSD patients is laid out in detail in a recent position statement issued by the Indian Society of Critical Care Medicine. ${ }^{[6]}$

Table 2 lists the reasons for not being able to retrieve organs from the BSD cases, the most common being lack of consent from the patients' families and shock with multi-organ failure, and other reasons being discharge against medical advice and infectious diseases.

This study looks at the trends of organ donation in a large Indian city. Most studies on organ donation following BSD have been done outside the Indian setting. Organ donation rates in other studies from India range from 5\% to $48 \%{ }^{[7,8]}$ In this study, the organ donation rate is shown to have risen sharply from 2 of 17 BSD cases (11\%) in the earlier part of the study to 4 of $10(40 \%)$ BSD cases in the latter period, which is on par with western countries. ${ }^{[9,10]}$ This improvement could be attributed to the role of well-trained, around the clock intensive care physicians in diagnosing and managing potential organ donors, in a closed ICU setup. Intensivists play a major role in counseling the family members and implementing standardized protocols in the care of BSD patients. ${ }^{[1]}$ In the latter years, the appointment of transplant coordinators, to liaise and build rapport with the families of the BSD patients, and the presence of an in-house transplantation team including liver and kidney transplant surgeons have contributed to the improvement in organ donation rates.

A prospective study by Seth et al. lists the various reasons for the refusal of organ donation by the patients' families, the most common being lack of consensus among family members toward donation. ${ }^{[12]}$ Further studies can help in anticipating

\begin{tabular}{lcccc}
\hline \multicolumn{2}{l}{\begin{tabular}{l} 
Table 1: Causes of brainstem death and number of organ donations over in each interval in the $\mathbf{9}$ years study period \\
\hline Study interval
\end{tabular}} & Trauma & $\begin{array}{c}\text { Total BSD in the } \\
\text { study interval }\end{array}$ & $\begin{array}{c}\text { Organ donations (percentage of } \\
\text { total BSD in the study interval) }\end{array}$ \\
\hline $2009-2011$ & 7 & 10 & 17 & $2(11.7)$ \\
$2012-2014$ & 12 & 16 & 28 & $4(14.2)$ \\
$2015-2017$ & 5 & 5 & 10 & $4(40.0)$ \\
Total (2009-2017) & 24 (ICH-13, stroke-8, HIE-3) & 31 (RTA-23, fall-8) & 55 & $10(18.18)$ \\
\hline
\end{tabular}

BSD: Brainstem death; ICH: Intracranial hemorrhage (nontraumatic); HIE: Hypoxic-ischemic encephalopathy; RTA: Road traffic accident

Table 2: Reasons for nonconversion of brainstem deaths into organ donation 
reasons for refusal and the areas to focus on, in improving the conversion rates.

\section{Financial support and sponsorship \\ Nil.}

\section{Conflicts of interest}

There are no conflicts of interest.

Shivakumar Mutnal, Pradeep Rangappa, Ipe Jacob, Karthik Rao Department of Critical Care, Columbia Asia Referral Hospital, Bengaluru, Karnataka, India

Address for correspondence: Dr. Pradeep Rangappa, Department of Critical Care, Columbia Asia Referral Hospital, Malleswaram West, Bengaluru - 560 055, Karnataka, India. E-mail: prangap939@gmail.com

\section{References}

1. Pandit RA, Zirpe KG, Gurav SK, Kulkarni AP, Karnath S, Govil D, et al. Management of potential organ donor: Indian society of critical care medicine: Position statement. Indian J Crit Care Med 2017;21:303-16.

2. Dhanwate AD. Brainstem death: A comprehensive review in Indian perspective. Indian J Crit Care Med 2014;18:596-605.

3. Wig N, Gupta P, Kailash S. Awareness of brain death and organ transplantation among select Indian population. J Assoc Physicians India 2003;51:455-8.

4. Kumar L. Brain death and care of the organ donor. J Anaesthesiol Clin Pharmacol 2016;32:146-52.

5. ORGAN India. A study of the deceased organ donation environment in Delhi/NCR. An initiative of the Parashar Foundation in Partnership with MOHAN Foundation; 2014. Available from: http://www.organindia. org/wp-content/uploads/2014/11/ORGAN-Research-Report.pdf. [Last accessed on 2018 Sep 10].

6. Ministry of Law, Justice and Company Affairs (Legislative Department). The Transplantation of Human Organs (Amendment) Act, 2011. New Delhi: Government of India. Available from: http://www.notto.nic. in/WriteReadData/Portal/images/THOA-amendment-2011.pdf. [Last accessed on 2018 Sep 10].

7. Sawhney C, Kaur M, Lalwani S, Gupta B, Balakrishnan I, Vij A, et al. Organ retrieval and banking in brain dead trauma patients: Our experience at level-1 trauma centre and current views. Indian J Anaesth 2013;57:241-7.

8. Amalorpavanathan J, Shroff S, Karunakaran CE, Castro R. Annual report from Tamil Nadu organ sharing registry for the year 2013. Chennai; 2014. Available from: http://www.tnos.org/pdf/report.pdf. [Last accessed on 2018 Sep 10].

9. Gómez MP, Arredondo E, Páez G, Manyalich M. International registry in organ donation and transplantation 2010. Transplant Proc 2012;44:1592-7.

10. Johnson RJ, Bradbury LL, Martin K, Neuberger J; UK Transplant Registry. Organ donation and transplantation in the UK-the last decade: A report from the UK national transplant registry. Transplantation 2014;97 Suppl 1:S1-27.

11. Palaniswamy V, Sadhasivam S, Selvakumaran C, Jayabal P, Ananth SR Organ donation after brain death in India: A trained intensivist is the key to success. Indian J Crit Care Med 2016;20:593-6.

12. Seth AK, Nambiar P, Joshi A, Ramprasad R, Choubey R, Puri P, et al. First prospective study on brain stem death and attitudes toward organ donation in India. Liver Transpl 2009;15:1443-7.

This is an open access journal, and articles are distributed under the terms of the Creative Commons Attribution-NonCommercial-ShareAlike 4.0 License, which allows others to remix, tweak, and build upon the work non-commercially, as long as appropriate credit is given and the new creations are licensed under the identical terms.

\begin{tabular}{|l|l}
\hline \multicolumn{3}{c}{ Access this article online } \\
\hline Quick Response Code: & Website: \\
& www.ijccm.org \\
& \\
&
\end{tabular}

How to cite this article: Mutnal S, Rangappa P, Jacob I, Rao K. Organ donation rate in brain-dead patients in a tertiary referral center. Indian J Crit Care Med 2018;22:685-6.

C 2018 Indian Journal of Critical Care Medicine | Published by Wolters Kluwer - Medknow 